\title{
Chemical Characteristics of Passiflora Caerulea Sedd Oil and Residual Seed Meal
}

\author{
O.E. Quiroga ${ }^{1}$, S. Bou ${ }^{1}$, M.S.Vigo ${ }^{2}$ and S.M. Nolasco ${ }^{1}$ \\ ${ }^{1}$ Facultad de Ingeniería. Universidad Nacional del Centro de la Prov. Bs. As. Avda. Del Valle 5737, \\ B7400JWI Olavarría, Prov. de Buenos. Aires, Argentina \\ ${ }^{2}$ Dpto de Química Orgánica. Area Bromatología. Facultad de Ciencias. Exactas y Naturales. U.B.A. \\ Ciudad Universitaria, Pabellón 2; 1428 - Buenos Aires, Argentina
}

\begin{abstract}
Seeds from Passiflora caerulea were defatted with n-hexane yielding 29,9\% of crude oil (dry basis). The crude oil was examined in their physicochemical characteristics. Fatty acid composition value showed only three acids in significative proportion: 16:0, 18:1 and 18:2. The residual seed meal analysis included: moisture value, ash, metals content, sugars, crude fiber, protein and available lysine.
\end{abstract}

\section{Introduction}

Passiflora caerulea, commonly known as "passion blue flower", is one of the 400 species that belong to the Passiflora genre (Passifloraceae family). It is cultivated for ornamentation and, as it is considered to have sedative and anticonvulsive properties, it is being used in homeophatic treatments. Also its fruit is eatable. This research work has investigated the chemical characteristics of Pasiflora caerulea seed oil and residual seed meal.

\section{Materials and Methods}

The seeds harvested in Olavarría (Province of Buenos Aires, Argentina), were manually separated from the ripe fruit. After having determined their physical characteristics, the seeds were ground. The seed oil was extracted from crushed seeds with n-hexane in a Soxhlet apparatus followed by evaporation of the solvent in a rotary evaporator. The oil content in the seeds was determined gravimetrically. Remaining solvent was removed from the residual meal $\left(45^{\circ} \mathrm{C}-50^{\circ} \mathrm{C}\right.$, vacuum).

The physical and chemical characteristics of the lipid fractions were determined according to the methods: AOAC, AOCS, IUPAC. The fatty acid composition was analysed by means of gas chromatography/mass spectrometry (GC-MS). The methyl esters of the total fatty acids was investigated spectrophotometrically (FTIR, UV).

The residual meal characteristics were determined according to the methods of the AOAC, AOCS 
and specifics.

\section{Results and Discussion}

The seed moisture value was $6.5 \%$. The crude oil extracted with $n$-hexane (soxhlet) turned to be gray, limpid at room temperature with a pleasant smell and a $29,9 \%$ (dry basis) yield. It presented the following characteristics: refractive index: $\left(25^{\circ} \mathrm{C}\right)$; 1,4709; iodine index: 132; acid value: 2,4; saponification value $(\mathrm{mg} \mathrm{KOH} / \mathrm{g}): 171$; unsaponifiable matter $(\%): 2,6$; iodine value of the unsaponifiable matter: 150,5 ; total phosphorous ( $\mu \mathrm{g} / \mathrm{g}$ ) 127 ; total sterols (\% as sitosterol): 0,27 ; peroxide index: 2,8 .

The acid composition demonstrates that the major components of the Passiflora caerulea L. oil are the acids 18:2 $(63,1 \%), \mathbf{1 8 : 1}(17,6 \%)$ and 16:0 (10,1\%). There is a low concentration of the acid 18:3. $4 \%$ of the acid composition belongs to the fatty acids with more than eighteen-carbon atoms.

All the methyl esters ultraviolet spectrophotometric analysis disclosed a low concentration of conjugated diene, triene and tetraene $\left(\% \mathrm{C}_{2}=0,56 ; \% \mathrm{C}_{3}=0,04\right)$.

The FTIR analysis of Passiflora caerulea L. oil, detected the presence of conjugate diene and the hydroxyl group.

The residual meal proteic content $(23,8 \%)$ and the available lysine value fulfil the requirements suggested by the Food and Agriculturue Organization of the United Nation (F.A.O.)

From this first explorative research work it is possible to foresee, previous verification of the seed innocuousness and digestibility, a potencial utilization of these seeds, mainly from the nutritional point of view.

Table 1. Chemical composition of residual meal.

\begin{tabular}{lclc}
\hline Dry material $(\%)$ & 92,8 & Urease activity & 0,25 \\
Ash $(\%)$ & 4,3 & Copper $(\mu \mathrm{g} / \mathrm{g})$ & 62 \\
Crude Protein $(\mathrm{Nx}$ 6,25) $(\%)$ & 23,8 & Calcium $(\mu \mathrm{g} / \mathrm{g}))$ & 77 \\
Crude fiber $(\%)$ & 32,5 & Phosphorus $(\mu \mathrm{g} / \mathrm{g})$ & 3270 \\
Available lysine (g/16g N) & 4,49 & Zinc $(\mu \mathrm{g} / \mathrm{g})$ & 75 \\
Reducing sugars \% (as glucose) & 7,4 & Magnesiun $(\mu \mathrm{g} / \mathrm{g})$ & 1640 \\
Non reducing Sugars \% (as sucrose) & 1,6 & Sodium $(\mu \mathrm{g} / \mathrm{g})$ & 2500 \\
Hydrolizable Carbohydrates \% (as starch) & 4,7 & & \\
\hline
\end{tabular}

\# All the results are in dry basis.

Acknowledgements: This research was supported by the Universidad Nacional del Centro de la Provincia de Buenos Aires and Comisión de Investigaciones Científicas de la Provincia de Buenos Aires (Argentina). 


\section{References and Notes}

1. Medina, J.H.; Paladini, A.C.; Wolfman, C.; Levi de Stein, M.; Diaz, L.E.; Pena. C. Biochem. Pharmacol 1990, 40(10), 2227.

2. Official Methods of Analysis of Association of the Official Analytical Chemists; Horwitz, W., Ed.; AOAC-Association of Official Analytical Chemists: Washingtong D.C, 1990.

3. Official and Tentative Methods of the American Oil Chemists'Society; AOCS - American Oil Chemists Society: Champaing, Illinois,1963. 